\title{
PRAKTIK JASA LAUNDRY CHESTA BARELEJO MADIUN PERSPEKTIF HUKUM ISLAM
}

\author{
Siti Fatimah \\ Madiun \\ sitifatimahdm25@gmail.com
}

\begin{abstract}
This is a of field research to highlight on "the Practice of Service of Loundry Chesta Balerejo Madiun" which aims to answer the two fundamental questions: (1) how is the practice of Loundry Chesta Balerejo Madiun? and how is the Review of Islamic Law on Loundry Chesta Balerejo Madiun?. The results of the study concluded that: first, in the practice of Loundry Chesta Balerejo Madiun, consumers came to bring their dirty clothes for laundry, then the dirty clothes were weighed by the laundry owner. The results of the scales and nominal prices were not stated and there was no evidence, either in the form of receipts or notes, so it was only known when the clothes were taken after being washed. In this case, most consumers are willing and do not feel disadvantaged and use the service again; second, the practice of Loundry Chesta Balerejo Madiun above is in accordance with Islamic law because it has fulfilled the pillars and conditions for a valid contract, where the perpetrator of contract is already 'aqil baligh and consists of two people, the object of the contract is clear and known to both parties. As for the case of sighat, although the laundry party did not mention it directly, both parties did not feel aggrieved and mutually agreed to each other. This is allowed by the majority of scholars except for Syafi'iyah scholars.
\end{abstract}

\section{Keywords: Laundry, Ijarah, Islamic Law}

\begin{abstract}
Abstrak: Penelitian ini merupakan hasil penelitian lapangan (field research) tentang "Praktik Jasa Loundry Chesta Balerejo Madiun" yang bertujuan untuk menjawab pertanyaan tentang bagaimana praktik jasa loundry Chesta Balerejo Madiun? dan bagaimana Tinjauan Hukum Islam Terhadap Praktik Jasa Loundry Chesta Balerejo Madiun?. Hasil penelitian menyimpulkan bahwa: pertama, dalam praktik jasa loundry Chesta Balerejo Madiun, konsumen datang membawa pakaian kotornya untuk diloundry, kemudian pakaian kotor tersebut ditimbang oleh pemilik loundry. Adapun hasil timbangan dan nominal harganya tidak disebutkan serta tidak adanya bukti, baik berupa kuitansi atau nota, sehingga baru diketahui ketika pakaian diambil setelah diloundry. Dalam hal ini, kebanyakan konsumen rela dan tidak merasa dirugikan serta menggunakan lagi jasa tersebut; kedua, Praktik jasa loundry Chesta di atas telah sesuai dengan hukum Islam karena sudah memenuhi rukun dan syarat sahnya akad, di mana pelaku akad sudah 'áqil baligh dan terdiri dari dua orang, objek akad jelas dan diketahui kedua belah pihak. Adapun dalam hal sighat, walaupun pihak loundry tidak menyebutkan secara langsung, namun kedua belah pihak tidak merasa dirugikan dan saling sepakat satu sama lain. Hal ini diperbolehkan oleh jumhur ulama' kecuali ulama' Syafi'iyah .
\end{abstract}

Kata Kunci: Laundry, Ijarah, Hukum Islam

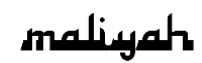

Jurnal Hukum Bisnis Islam

Volume 10, Nomor 02, Desember 2020

p-ISSN: 2088-4869/ e-ISSN: 2597-4351 


\section{Pendahuluan}

Pada hakikatnya Allah menciptakan manusia di alam ini tidak lain hanya untuk beribadah kepadanya. Manusia juga merupakan makhluk sosial yang tidak bisa hidup sendiri tanpa adanya interaksi sosial dengan yang lainnya, guna untuk memenuhi kebutuhan hidup dan kelangsungan hidupnya. Kehidupan manusia merupakan satu kesatuan yang menimbulkan hubungan timbal balik antara manusia itu sendiri, sehingga masyarakat saling berhubungan satu sama lain untuk mencukupi kebutuhan kebutuhan hidupnya. ${ }^{1}$ Tatacara dan pelaksanaan kehidupan tersebut telah diatur dalam al qur'an dan al-Hadis secara benar, demi mendapatkan rida dan memperoleh derajat yang tinggi disisinya.

Kata "mu'amalah" menggambarkan suatu peraturan Allah Swt yang harus diikuti dan ditaati dalam kehidupan masyarakat. Mu'amalah juga dipahami sebagai aturan yang mengatur hubungan manusia dengan manusia dalam mengembangkan dan memperoleh harta. Beberapa contoh muamalah sesama manusia adalah jual beli, sewa menyewa, upah mengupah, gadai, salam, pindahan utang, serta yang lain. ${ }^{2}$

Tidak semua umat Islam yang mengerti pelaksanaan kegiatan mua'malah dengan benar. Dalam pelaksaannya mua 'malah juga memiliki larangan-larangan dan aturan yang harus diperhatikan dan tidak boleh dilanggar. Seiring dengan berjalannya waktu, banyak larangan-larangan yang dilarang fikih mua 'malah tapi justru dilakukan dalam kehidupan seharihari dan sudah menjadi kebiasaan dan rutinitas. Contohnya seperti riba, gharar, dan batil. ${ }^{3}$ Dengan demikian, manusia harus tolong-menolong untuk tercapainya kepentingan dan

\footnotetext{
${ }^{1}$ Ahmad Azhar Basyir, Asas-Asas Hukum Muamalah (Hukum Perdata Islam) (Yogyakarta: UII Press, 2000). 11

${ }^{2}$ Nasrun Harun, Fiqh Muamalah (Jakarta: Gaya Media Pratama, 2000).7

${ }^{3}$ Mardani, Fiqih Ekonomi Syariah (Fiqih Muamalah) (Jakarta: Kharisma Putra Utama, 2012).6
} 
tujuan masing-masing yang tentunya tidak keluar dari aturanaturan syara'. Seperti firman Allah Swt dalam surah al-Māidah ayat 2 yang berbunyi:

"Hai orang-orang yang beriman, janganlah kamu melanggar syi'ar syi'ar Allah, dan jangan melanggar kehormatan bulan-bulan haram, jangan (mengganggu) binatang-binatang had-ya, dan binatang-binatang qalaid, dan jangan (pula) mengganggu orang orang yang mengunjungi Baitullah sedang mereka mencari kurnia dan keridhaan dari Tuhannya dan apabila kamu telah menyelesaikan ibadah haji, maka bolehlah berburu. Dan janganlah sekali-kali kebencian(mu) kepada sesuatu kaum karena mereka menghalang-halangi kamu dari Masjidil haram, mendorongmu berbuat aniaya (kepada mereka). Dan tolong-menolonglah kamu dalam (mengerjakan) kebajikan dan takwa, dan jangan tolongmenolong dalam berbuat dosa dan pelanggaran. Dan bertakwalah kamu kepada Allah, sesungguhnya Allah amat berat siksa-Nya."4

Tolong menolong yang diatur dalam hukum Islam sangatlah banyak, dan semua bentuk tolong menolong yang diatur dalam hukum Islam harus didasari dengan transaksi (akad). Dalam bidang muamalat, salah satu akad yang dipelajari adalah akad ijarah.

Mayoritas ulama memperbolehkan akad ijarah dengan dalil Al-Qur'an dalam Qs al-Talāq ayat 6

"Tempatkanlah mereka (para isteri) di mana kamu bertempat tinggal menurut kemampuanmu dan janganlah kamu menyusahkan mereka untuk menyempitkan (hati) mereka. Dan jika mereka (isteri-isteri yang sudah ditalaq) itu sedang hamil, maka berikanlah kepada mereka nafkahnya hingga mereka bersalin, kemudian jika mereka menyusukan (anakanak)mu untukmu maka berikanlah kepada mereka upahnya, dan musyawarahkanlah di antara

\footnotetext{
${ }^{4}$ Departemen Agama Republik Indonesia, Al Qur'an Dan Terjemahnya (Jakarta: CV Karya Insan Indonesia, 2002).349
} 
kamu (segala sesuatu) dengan baik; dan jika kamu menemui kesulitan maka perempuan lain boleh menyusukan (anak itu) untuknya."

Dalam surah al-Qașaș 26-27

"Salah seorang dari kedua wanita itu berkata: "Ya bapakku ambillah ia sebagai orang yang bekerja (pada kita), karena sesungguhnya orang yang paling baik yang kamu ambil untuk bekerja (pada kita) ialah orang yang kuat lagi dapat dipercaya" (QS al-Qasās 26). Berkatalah dia (Syu'aib): "Sesungguhnya aku bermaksud menikahkan kamu dengan salah seorang dari kedua anakku ini, atas dasar bahwa kamu bekerja denganku delapan tahun dan jika kamu cukupkan sepuluh tahun maka itu adalah (suatu kebaikan) dari kamu, maka aku tidak hendak memberati kamu. Dan kamu Insya Allah akan mendapatiku termasuk orangorang yang baik."6

Secara terminologi perlu dikemukakan pendapat para ulama', antara lain:

1. Menurut ulama' Malikiyah dan Hanabilah, ijarah adalah pemilikan suatu manfaat yang diperbolehkan dalam waktu tertetentu dengan imbalan.

2. Menurut ulama' Syafi'iyah, ijarah adalah transaksi terhadap sesuatu manfaat yang dimaksud, tertentu, bersifat mubah dan boleh dimanfaatkan dengan imbalan tertentu.

3. Menurut Ali al-Khafif, ijarah adalah transaksi terhadap sesuatu yang bermanfaat dengan imbalan.

Berdasarkan beberapa definisi tersebut, maka ijarah tidak boleh dibatasi dengan syarat. Akad ijarah tidak boleh dipalingkan, kecuali ada unsur manfaat, dan akad ijarah tidak boleh berlaku pada pepohonan untuk diambil buahnya. ${ }^{7}$

\footnotetext{
${ }^{5}$ Ibid.946

${ }^{6}$ Ibid. 279

${ }^{7}$ Abu Azam Al Hadi, Fiqh Muamalah Kontemporer (Sidoarjo: CV Cahaya XII, 2014).72-73
} 
Dilihat dari objeknya, para ulama fikih membagi akad ijarah kepada dua macam:

1. Ijarah bi al-'amal, yaitu sewa menyewanya yang bersifat pekerjaan/jasa. Ijarah yang bersifat pekerjaan/jasa ialah dengan cara memperkerjakan seseorang untuk melakukan suatu pekerjaan. Menurut para ulama fiqh, ijarah jenis ini hukumnya diperbolehkan apabila jenis pekerjaan itu jelas, seperti buruh bangunan, tukang jahit, buruh pabrik dan tukang sepatu. Ijarah seperti ini terbagi menjadi dua yaitu:

a. Ijarah yang bersifat pribadi, seperti menggaji seseorang pembantu rumah tangga.

b. Ijarah yang bersifat serikat yaitu, seseorang atau sekelompok orang yang menjual jasanya untuk kepentingan orang banyak seperti tukang sepatu, buruh pabrik dan tukang jahit. Kedua bentuk ijarah terhadap pekerjaan ini (buruh, tukang dan pembantu), menurut para ulama fiqh hukumnya boleh.

2. Ijarah bi al-manfa'ah, yaitu sewa menyewanya yang bersifat manfaat. Ijarah yang bersifat manfaat contohnya:

a. Sewa-menyewa rumah.

b. Sewa-menyewa toko.

c. Sewa-menyewa kendaraan.

d. Sewa-menyewa pakaian.

e. Sewa-menyewa perhiasan dan lain-lain. ${ }^{8}$

Sewa-menyewa sebagai akad akan berakhir sesuai kata sepakat Dalam perjanjian. Dengan berakhirnya suatu sewa menyewa ada kewajiban bagi penyewa untuk menyerahkan barang yang disewakan. ${ }^{9}$ Selain itu, hak dan kewajiban yang menawarkan jasa dan yang menikmati jasa harus terpenuhi. Adapun kewajiban pemberi jasa adalah memenuhi semua keawajiban yang tertuang dalam perjanjian kerja, dia harus

\footnotetext{
${ }^{8}$ Muhammad Yazid, Hukum Ekonomi Islam (Fiqh Muamalah) (Sidoarjo: CV Cahaya Intan XII, 2014).202

${ }^{9}$ Abdul Djamali, Hukum Islam (Bandung: Mandar Maju, 1992, 1992).161
} 
bersungguh-sungguh mengerahkan kemampuannya sesuai dengan syarat-syarat kerja secara efisien dan jujur. ${ }^{10}$

Apabila yang menjadi objek transaksi itu adalah manfaat atau jasa dari suatu benda disebut ijarah al-'ayn. Seperti, sewa menyewa rumah yang ditempati Bila yang terjadi objek transaksi manfaat atau jasa dari tenaga seseorang disebut dengan ijarāh dimmah atau upah mengupah seperti upah buru pabrik. Sekalipun objeknya berbeda keduanya dalam konteks fikih disebut ijārah. ${ }^{11}$

Sedangkan menurut istilah atau terminologi, para fuqoha berbeda pendapat mengenai pengertian ijarah, tetapi pada dasarnya ijarah adalah sebuah akad pemindahan hak guna atas barang atau jasa melalui pembayaran atau upah atau imbalan, tanpa diikuti dengan pemindahan kepemilikan. ${ }^{12}$

Jasa merupakan suatu tindakan atau aktivitas yang ditawarkan pada pihak lain dan tidak berwujud tetapi bisa dinikmati manfaatnya. Sebuah jasa itu mencakup semua aktivitas ekonomi yang hasilnya bukanlah produk atau kontruksi fisik, yang secara umum konsumsi dan produksinya dilakukan pada saat bersamaan, dan nlai tambah yang diberikannya dalam bentuk (kenyamanan, hiburan, kecepatan, dan kesehatan) yang secara prinsip tidak berwujud pada pembeli pertamanya. ${ }^{13}$

Dalam penentuan tarif pencucian pakaian (loundry) perusahaan melihat dari segi berat timbangan pakaian yang akan di loundry. Dan pemberian tarif tersebut merupakan upah yang diberikan pelanggan kepada pihak jasa loundry sebagai imbalan atas pencucian pakaian. Maka pelanggan harus

\footnotetext{
${ }^{10}$ Muhammad Syarif Chaudrhry, Sistem Ekonomi Islam ; Prinsip Dasar (Jakarta: Prenamedia Group, 2012). 195

${ }^{11}$ Amir Syarifuddin, Garis-Garis Besar Fiqh (Jakarta: Kencana, 2003).216

${ }^{12}$ Harun, Fiqh Muamalah.228

${ }^{13}$ Diyah Santi Hariyani, “'Analisa Kontribusi Pembiayaan Musyarakah, Murabahah Dan Ijārah Terhadap Profitabilitas (Roe) Pada Bank BNI Syariah"” (Skripsi--STIE Dharma Iswara Madiun, 2017).
} 
memberikan upah yang pantas. Hal ini agar sesuai dengan firman Allah dan surat al-Baqarah ayat 233 yang berbunyi:

"Dan jika kamu ingin anakmu disusukan orang lain, Maka tidak ada dosa bagimu apabila kamu memberikan pembayaran yang patut. Bertaqwalah kamu kepada Allah dan ketehuilah Allah Maha melihat apa yang kamu kerjakan".14

Menurut hukum Islam, untuk melakukan transaksi sewa-menyewa harus memenuhi syarat yang telah ditentukan. Para ulama' fiqh telah merumuskan sekian banyak rukun dan syarat sahnya sewa-menyewa yang telah mereka pahami dari nash-nash al qur'an maupun dari hadis-hadis Rasulullah saw., adanya yang berakad, manfaat atau imbalan, shighat (ijabqabul). ${ }^{15}$ sedangkan syarat sahnya adalah adanya kerelaan dari kedua belah pihak yang melakukan akad, mengetahui manfaat dengan sempurna barang yang diakadkan sehingga mencegah terjadinya perselisihan, hendaklah yang jadi objek transaksi (akad) dapat dimanfaatkan kegunaannya menurut kriteria, realita dan syara'. Dapat diserahkannya sesuatu yang disewakan berikut kegunaan (manfaatnya) bahwa manfaat adalah hal yang mubah bukan hal yang diharamkan. ${ }^{16}$ Hal-hal tersebut adalah rukun dan syarat sah dari sewa-menyewa, meskipun ada perbedaan pendapat antara suatu ulama madzhab dengan ulama madzhab lainnya. Perbedaan ini tidak hanya terletak pada sumber hukum atau bunyi nash yang bersifat normatif, tetapi juga dilatarbelakangi oleh tingkat perbedaan pemahaman masing-masing ulama dengan kondisi zaman, situasi tempat dan metodologi yang digunakan dimana aturan digunakan.

Dari pengertian di atas dijelaskan bahwa sewamenyewa merupakan bagian dari kegiatan muamalah. Dalam masa kini, sewa menyewa banyak dilakukan oleh masyarakat

\footnotetext{
${ }^{14}$ Departemen Agama Republik Indonesia, Al Qur'an Dan Terjemahnya.57

${ }^{15}$ Harun, Fiqh Muamalat.231

${ }^{16}$ Sayyid Sabiq, Fiqh Sunnah (Bandung: PT. Al-Ma'arif, 1987).12-13
} 
dikarenakan masyarakat hanya ingin memanfaatkan sementara barang tersebut atau sebagian dari jasa yang ditawarkan oleh pihak yang menyewakan suatu barang atau jasa tersebut. Salah satunya ialah jasa sarana loundry yang sekarang ini dibutuhkan oleh sebagian besar masyarakat. Salah satunya adalah loundry Chesta. Usaha loundry Chesta ini marak dikembangkan oleh pebisnis di negara Indonesia ini.

Sering dengan perkembangan zaman, berkembang pulah pola pikiran dan kebutuhan masyarakat. Tidak dapat dipungkiri bahwa kebutuhan konsumsi dan lain sebagiannya telah meningkat. Begitu pula dengan kebutuhan yang meningkat sehingga perlu juga peayanan yang cepat, efektif dan efisien.

Dengan adanya hubungan sewa-menyewa ini, maka kedua belah pihak telah terikat dalam suatu perjanjian atau di dalam kajian fiqh múāmalah dikenal dengan istilah ijarah yaitu akad atas suatu kemanfaatan dengan pengganti. ${ }^{17}$ Adapun jangka sewa ditentukan oleh penyewa atau ditetapkan berdasarkan kesepakatan kedua belah pihak.

Bisnis jasa pada era yang modern ini banyak dinikmati oleh masyarakat yang ingin serba praktis dalam pemenuhan kebutuhannya. Saat ini terdapat berbagai macam sektor jasa seperti jasa konsultan, jasa penyewaan penginapan, jasa pencucian pakaian (loundry), jasa rekreasi, jasa kesehatan, jasa komunikasi, jasa transportasi, jasa keuangan, jasa pendidikan, dan sebagainya. Macam-macam jasa tersebut sedikit banyak dilakukan untuk pemenuhan kebutuhan dalam kegiatan seharihari. Salah satu bidang usaha jasa yang dibutuhkan untuk kebutuhan sehari hari adalah jasa pencucian pakaian (loundry). Jasa ini sangat dibutuhkan bagi orang yang tidak memiiki waktu banyak atau pun malas untuk mencuci pakaiannya sendiri. Perusahaan jasa loundry ini sangat berkembang pesat,

\footnotetext{
${ }^{17}$ Syafe'i Rachmat, Fiqh Muamalah Untuk IAIN, STAIN, PTAIS Dan Untuk Umum, Cet I (Bandung: Pustaka Setia, 2001).121
} 
karena banyak sekali tempat-tempat loundry yang ada disekeliling kita.

Banyaknya usaha jasa loundry disebabkan oleh semakin banyaknya peminat dalam sektor jasa ini, selain itu biaya yang ditawarkan relatif murah, pengelolaan yang tidak terlalu sulit dan dengan prosentase keuntungan yang menjanjikan. Dimadiun saja sudah tidak terhitung beberapa jumlah perusahaan loundry yang ada. Masing-masing perusahaan berlomba-lomba berusaha memberikan pelayanan yang terbaik bagi pengguna jasanya. ${ }^{18}$

Masyarakat sekitar Balerejo Madiun sering menggunakan jasa loundry Chesta untuk membantu mencuci pakaian. Akan tetapi dalam melakukan transaksi jasa loundry tidak adanya akad di awal, tidak adanya kejelasan berat timbanagan baju yang akan di loundry konsumen terlebih dahulu, tidak adanya nota, tidak ada kejelasan patokan harga perkilogram. Jasa loundry yang ditawarkan oleh loundry Chesta antara lain: cuci kering, cuci setrika, cuci mamel, dry clean, jasa setrika, wanter. Seperti diketahui jasa loundry ini sudah berjalan 2 tahun dan tidak hanya masyarakat Balerejo aja yang menggunakan jasa ini tetapi juga desa-desa sekitar Balerejo.

Dari uraian latar belakang di atas, bedanya dengan penelitian-penelitian diatas membahas tentang pembulatan loundry sedangkan peneliti dengan judul tinjauan hukum Islam terhadap praktik jasa loundry Chesta Balerejo Madiun akan fokus ke praktik jasa loundry Chesta Balerejo Maiidun dan hukum Islam terhadap praktik jasa loundry Balerejo Madiun.

Penelitian tentang ini merupakan penelitian lapangan (field research) yakni jenis penelitian yang dilakukan dengan mengumpulkan di lapangan. Sedangkan pendekatan yang digunakan adalah penelitian kualitatif, karena kualitatif memuat tentang prosedur penelitian yang menghasilkan data

${ }^{18}$ Afi, Wawancara, Madiun, 15 Februari 2018.

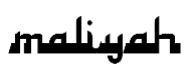

Jurnal Hukum Bisnis Islam Volume 10, Nomor 02, Desember 2020 p-ISSN: 2088-4869/ e-ISSN: 2597-4351 
deskriptif, berupa kata-kata tertulis atau lisan dari orang-orang dan perilaku yang diamati.

\section{Ijarah}

Menurut sayyid sabiq ijarah berasal dari kata al-ajru yang berarti Al 'Iwadhu (ganti). Dari sebab itu Al sawwab (pahala) dinamai ajru (upah) ${ }^{19}$. Secara bahasa menurut Rahmad Syafi'i, seperti yang dikutip oleh Sohari Sahrani dan Ruf'ah Abdullah dalam bukunya fikih múāmalah, menyatakan bahwa ijarah secara bahasa adalah bay'ul manfa'ah (menjual manfaat). ${ }^{20}$

Menurut Saleh al Fauzan, ijarah ada dua jenis. Jenis yang pertama adalah ijarah yang berlangsung atas manfaat yang berasal dari benda tertentu atau dari benda yang disebutkan ciri-cirinya. Jenis yang kedua adalah menyewa (mengupah) orang untuk pekerjaan tertentu. ${ }^{21}$

Dari beberapa definisi di atas, dapat ditarik kesimpulan bahwa ijarah adalah akad atau transaksi sewa-menyewa atas suatu barang dalam waktu tertentu melalui pembayaran sewa tanpa diikuti dengan pemindahan kepemilikan atas barang itu sendiri dana atau upah mengupah atas suatau jasa dalam waktu tertentu dengan imbalan jasa (upah).

Secara terminologi perlu dikemukakan pendapat para ulama', antara lain:

1. Menurut Ali al-Khafif, ijarah adalah transaksi terhadap sesuatu yang bermanfaat dengan imbalan.

2. Menurut ulama' Syafi'iyah, ijarah adalah transaksi terhadap sesuatu manfaat yang dimaksud, tertentu, bersifat mubah dan boleh dimanfaatkan dengan imbalan tertentu.

\footnotetext{
${ }^{19}$ Sabiq, Fiqh Sunnah.7

${ }^{20}$ Sohari Sahrani and Ruf'ah Abdullah, Fikih Muamalah (Bogor: Ghalia Indonesia, 2005). 167

${ }^{21}$ Shaleh Al-Fauzan, Fikih Sehari-Hari, Terj. Abdul Hayyie Al-Kattani (Jakarta: Gema Insani Press, 2005).482
} 
3. Menurut ulama' Malikiyah dan Hanabilah, ijärah adalah pemilikan suatu manfaat yang diperbolehkan dalam waktu tertetentu dengan imbalan. ${ }^{22}$

4. Berdasarkan beberapa definisi tersebut, maka ijärah tidak boleh dibatasi dengan syarat. Akad ijärah tidak boleh dipalingkan, kecuali ada unsur manfaat, dan akad ijarah tidak boleh berlaku pada pepohonan untuk diambil buahnya. ${ }^{23}$

Bila dilihat dari uraian di atas, rasanya mustahil manusia hidup berkecukupan tanpa hidup berijarah dengan manusia lain. Karena itu, boleh dikatakan bahwa pada dasarnya ijarah itu adalah salah satu bentuk aktivitas antara dua belah pihak atau saling meringankan, serta termasuk salah satu tolong menolong yang diajarkan agama.

Ijarah merupakan salah satu jalan memenuhi hajat manusia. Oleh sebab itu, para ulama menilai bahwa ijarah ini merupakan suatu hal yang boleh dan bahkan kadang-kadang perlu dilakukan. Walaupun ada pendapat yang melarang ijarah, tetapi oleh jumhur ulama pandangan yang ganjil itu dipandang tidak ada. Banyak ayat dan riwayat yang dijadikan argument oleh para ulama akan kebolehan ijarah tersebut. ${ }^{24}$

Ijarah yang sah dibolehkan dalam al-Quran, As sunnah dan ijma'. Dalil-dalil dibolehkannya adalah sebagi berikut:

1. Dasar hukum al-Quran Al-Qasas 26

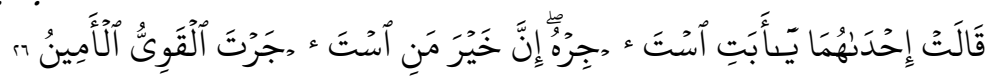

"Salah seorang dari kedua wanita itu berkata: "Ya bapakku ambillah ia sebagai orang yang bekerja (pada kita), karena sesungguhnya orang yang paling baik yang kamu ambil untuk bekerja (pada kita) ialah orang yang kuat lagi dapat dipercaya" 25

\footnotetext{
${ }^{22}$ Al Hadi, Fiqh Muamalah Kontemporer.72

${ }^{23}$ Ibid. 73

${ }^{24}$ Helmi Karim, Fiqih Muamalah, n.d.30

${ }^{25}$ Departemen Agama Republik Indonesia, Al Qur'an Dan Terjemahnya.280
} 
2. Dasar hukum As-sunnah

Para ulama menyempurnakan alasan diperbolehkannya ijarāh dan sabda Rasulullah saw diantaranya adalah:

Hadis Bukhari

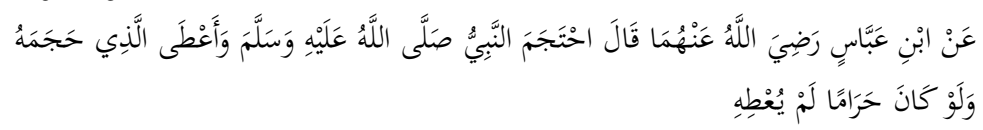

"Dari Ibn 'Abbās RA., katanya: Nabi Saw. Berbekam dan memberikan upah kepada orang yang membekamnya dan seandainya mengetahui kemakruhannya, niscaya ia tidak akan memberi upah kepadanya" (H.R. al-Bukhāri). ${ }^{26}$

3. Dasar hukum landasan ijma'

Mengenai disyari'atkan ijarah, semua umat bersepakat tak seorang pun yang membantah kesepakatan (ijma') ini, sekalipun ada beberapa orang diantara mereka yang berbeda pendapat, akan tetapi hal itu tidak dianggap. ${ }^{27}$

\section{Al 'aqd}

\section{Pengertian Akad}

Perikatan dan perjanjian dalam konteks fiqh múāmalah dapat disebut dengan akad. Kata akad berasal dari bahasa arabal-'aqd bantuk jamaknya adalah al-uqūd yang mempunyai arti perjanjian, persetujuan dan buah atau lebih perikatan. ${ }^{28}$

Adapun secara istilah (terminologi) ada beberapa pengertian akad, pengertian tersebut ada yang bersifat umum dan khusus. ${ }^{29}$

1. Pengertian akad secara umum adalah setiap yang diinginkan manusia untuk mengerjakannya, baik keinginan tersebut berasal dari kehendaknya sendiri, misalnya dalam hal wakaf, atau kehendak tersebut timbul dari dua orang, misalnya dalam hal jual beli dan ijarah.

\footnotetext{
${ }^{26}$ Al-Hafidz Ibnu Hajar Al-A'qalani, Bulughul Maram, Terj. Hamim Thohari Ibnu M Dalimi (Jakarta: PT Gramedia, n.d.).240

${ }^{27}$ Sabiq, Fiqh Sunnah. 11

${ }^{28}$ Qomarul Huda, Fiqh Muamalah (Yogyakarta: Teras, 2011).25

${ }^{29}$ Wahbah Zuhaili, Fiqih Islam Wa Adillatuhu, 2011.2971
} 
2. Pengertian akad secara khusus adalah perikatan yang ditetapkan ijab qabul berdasarkan ketentuan syara' yang berdampak pada objeknya.

Dalam akad biasanya dititik beratkan pada kesepakatan antara dua belah pihak yang ditandai dengan ijab qabul. Dengan demikian ijab qabul adalah suatu perbuatan dan pernyataan untuk menunjukkan belah pihak yang ditandai dengan ijab dan qabul. Dengan demikian ijab dan qabul adalah suatu perbuatan dan pernyataan untuk menunjukkan suatu keridhaan dalam berakad yang dilakukan oleh dua orang atau lebih, sehingga terhindar atau keluar dari suatu ikatan yang tidak berdasrkan syara'. Karena itu, dalam Islam tidak semua bentuk kesepakatan atau perjanjian dapat dikategorikan sebagai akad, terutama kesepakatan yang tidak didasarkan pada keridhaan dan syari'at Islam.

\section{Rukun-rukun akad}

Terdapat perbedaan pendapat di kalangan fuqaha berkenaan dengan akad. Menurut jumhur fuqaha rukun akad terdiri atas. ${ }^{30}$

a. Al-aqidayn, para pihak yang terlibat langsung dengan akad

b. Mabālul al'aqd, yakni obyek akad, yakni sesuatu yang hendak diakadkan.

c. Sighat al-'aqd, yakni pernyataan kalimat akad, yang lazimnya dilaksanakan melalui pernyataan ijab dan pernyataan qabul.

Metode șighat dalam akad dapat diungkapkan dengan beberapa cara. Diantarannya:

1. Akad dengan perbuatan

Dalam akad, terkadang tidak menggunakan ucapan, tetapi cukup dengan saling meridhoi. Seperti yang jama' pada zaman sekarang. Dalam menetapkan hal ini, Para ulama' berbeeda pendapat, yaitu:

${ }^{30}$ Ibid. 2930 
a. Ulama' Hanabilah dan Hanafiyah diperbolehkan akad dengan perbuatan terhadap barang yang umum diketahui manusia. Jika tidak umum, maka akad ini dianggap batal.

b. Imam Maliki dan Imam Ahmad berpendapat boleh tetapi dengan syarat harus jelas adanya kerelaan. Baik barang ini secara umum atau tidak.

c. Ulama Syafi'iyah, Syi'ah dan Dhahiriyah berpendapat bahwa akad tersebut tidak dibenarkan karena tidak dibenarkan karena tidak ada petunjukyang kuat hal itu. Adapun kerelaan merupakan sesuatu yang samar.

2. Akad dengan Isyarat

Bagi yang mampu berbicara, tidak diperbolehkan menggunakan isyarat. Bagi yang tidak bisa berbicara boleh menggunakan isyarat. Tetapi jika tulisanya bagus, maka lebih baik menggunakan tulisan. Hal ini dibolehkan jika dia memang cacat atau sejak lahir. Kalua tidak sejak lahir, maka dia harus berusaha untuk tidak menggunakan isyarat.

3. Akad dengan tulisan

Pada dasarnya, akad harus menggunakan ucapan. Tidak bisa membandingi akad dengan menggunakan ucapan kecuali memag dalam keadaan darurat.

Dibolehkan akad menggunakan tulisan, baik bagi orang yang mampu berbicara maupun tidak, dengan syarat tulisan harus jelas, tampak dan dapat difahami oleh keduanya.

Namun, jika kedua orang yang akad hadir dan bisa berbicara, maka tidak boleh menggunakan tulisan. Karena saksi harus mendengarkan perkataan orang yang akad. Iniah pendapat ulama' Hanafiyah.

Ulama' Syafiiyah dan Hanabilah berpendapat bahwa akad dengan menggunakan tulisan itu sah jika kedua orang akad yang tidak hadir. Jika hadir, maka akad dengan menggunakan tulisan tidak sah. Sebab tulisan tidak dibutuhkan.

\section{Syarat-syarat Akad}

Syarat akad secara umum dapat dibagi menjadi dua macam, yaitu syarat adanya (terbentuknya) akad dan syarat 
sahnya akad. Syarat adanya akad menuntut apabila syarat ini tidak terpenuhi, maka akad dianggap tidak ada atau tidak terbentuk dan akadnya disebut batal. Syarat sahnya akad, yaitu syarat di mana apabila tidak terpenuhi tidak berarti lantas akad tidak ada, atau tidak terbentuk. Bisa saja akadnya ada dan telah terbentuk karena syarat adanya (terbentuknya) telah terpenuhi, hanya saja akad dianggap belum sempurna dan masih memiliki kekurangan, dan dalam keadaan demikian akad tersebut oleh ahli-ahli hukum Hanafi disebut dengan akad fasid, dan harus dibatalkan.

Syarat-syarat adanya (shurụt al-'aqd) meliputi tujuh macam, diantaranya:

1. Beretemunya ijab dan qabul (adanya kata sepakat antara para pihak) ${ }^{31}$

2. Bersatunya majlis akad

3. Berbilangnya para pihak

4. Berakal/tamyíz

5. Objek akad dapat diserahkan

6. Objek akad ditentukan, dan

7. Objek dapat ditransaksikan atau dapat menerima hukum akad

Syarat sahnya akad ada lima macam, yaitu

1. Tidak ada paksaan (ikrah)

2. Tidak menimbulkan kerugian (darar)

3. Tidak mengandung ketidakjelasan (ghärar)

4. Tidak mengandung riba, dan

5. Tidak mengandung syarat fasid

Apabila syarat ada dan syarat sahnya akad terpenuhi, maka akad tersebut tergolong akad yang sah.

\section{Dalil Tentang Akad/Perjanjian}

Sumber keabsahan akad di dalam Islam, didasarkan pada Al qur'an dan al-Hadis. Di samping itu juga didukung oleh sumber hukum Islam yang lain, seperti ijma' (kesepakatan

${ }^{31}$ Huda, Fiqh Muamalah.32-33 
ulama) dan juga qiyas (teori perbandingan hukum). Ketika soal perjanjian, maka tidak lepas dari persoalan apakah umat Islam diperbolehkan membuat akad baru. Persoalan ini dibahas dalam konsep asas kebebasan berkontrak atau akad (al-mabda' huríyah ). Sumber hukum Islam dalam akad dijelaskan sebagai berikut:

1. Al-Qur'an

Dalil Al-Qur'an yang bisa digunakan untuk merujuk kebolehan akad adalah surat Al-Maidah ayat 1 :

"Hai orang-orang yang beriman, penuhilah akad-akad itu". ${ }^{32}$

Selain ayat di atas, Al qur'an Surat An-Nisa' ayat 29 yang berbunyi:

"Wahai orang-orang yang beriman, janganlah kkamu makan harta sesama dengan jalan batil, kecuali (jika makan harta sesama itu dilakukan) dengan cara tukar-menukar berdasarkan perizinn timbal balik (kata sepakat) di antara kamu". 33

2. Al-Hadis

Manusia diperbolehkan untuk membuat akad juga didasrkan pada dalil Hadis. Dalam sebuah hadis yang diriwayatkan oleh al-Hakim dari sahabat Abu Hurairah, Rasul bersabda: "Orang-orang Muslim itu senantiasa terikat kepada syaratsyarat (janji-janji) mereka". Hadis ini menunjukkan bahwa syarat-syarat atau janji-janji apa saja yang dibuat dan wajib untuk dipenuhi. Selain itu, juga pada merujuk pada hadis Nabi Muhammad Saw. yang berbunyi "Sesungguhnya jual beli itu berdasarkan kata sepakat" (hadis Riwayat Ibn Hibban dan Ibn Majah).

Berakhirnya akad dapat disebabkan karena pembatalan, kematian dan karena tidak adanya pihak lain dalam hal akad mawqüf.

1. Berakhirnya akad karena fasakh. Hal-hal ini yang menyebebkan timbulnya fasakhnya akad adalah sebagai berikut:

\footnotetext{
${ }^{32}$ Departemen Agama Republik Indonesia, Al Qur'an Dan Terjemahnya.280

${ }^{33}$ Ibid. 83
} 
a. Fasakh karena akadnya fasid (rusak)

b. Fasakh karena khiyar

c. Fasakh berdasarkan iqalah, yaitu terjadinya fasakh karena adanya kesepakatan kedua belah pihak.

d. Fasakh karena tidak adanaya realisasi.

e. Fasakh karena jatuh tempo atau tujuan akad telah terealisasi.

2. Berakhirnya akad karena kematian. Kematian menjadi penyebab berakhirnya akad seperti akad dalam ijärah, rahn, kafalah, syirkah dan wakälah.

3. Berakhirnya akad karena tidak adanya izin pihak lain. Akad akan berakhir apabila pihak yang mempunyai wewenang tidak mengizinkannya atau meninggal sebelum dia memberikan. ${ }^{34}$

\section{Praktik Jasa Laundry chesta Balerejo Madiun}

Dalam jasa pencucian pakaian atau loundry ini banyak dinikmati oleh masyarakat yang ingin serba praktis dalam pemenuhan kebutuhannya. Saat ini terdapat berbagai macam sektor praktik jasa pencucian pakaian atau loundry merupakan kegiatan yang memanfaatkan tenaga seseorang untuk melakukan sesuatu pekerjaan terutama dalam mencuci pakaian. Yakni loundry Chesta yang berada di Balerejo Madiun.

Dalam transaksinya konsumen diberikan pilihan layanan yang ada di loundy Chesta dan yang diinginkan oleh konsumen. Terdapat enam layanan yang diberikan, diantaranya cuci mamel, cuci kering, cuci kering + setrika, dry clean, jasa setrika, dan wenter. Setelah memilih dari salah satu layanan tersebut maka barang akan ditimbang. Setelah barang yang ditimbang loundry Chesta tidak memberitahukan berapa berat timbangan dan tidak ada atau tidak disebutkan nominal harga per kilogram pada awal akad untuk mencuci pakaian di loundry tersebut dan tidak mendapatkan kwitansi sebagai bukti transaksi, hanya ketika mengambil pakaian yang sudah selesai

${ }^{34}$ Ibid.48-49 
di loundry baru mengenai harga yang harus dibayar oleh konsumen. ${ }^{35}$

Dari transaksi yang terjadi di loundry Chesta Balerejo Madiun terdapat penyimpangan dalam pengaplikasian akad. Pada transaksi tersebut ada beberapa konsumen yang merasa dirugikan tetatapi ada juga konsumen yang merasa tidak dirugikan. Bagi konsumen yang tidak merasa dirugikan maka tidak masalah, tetapi bagi konsumen yang merasa dirinya dirugikan hal tersebut akan menjadi permasalahan tersendiri.

Kerugian yang diserahkan oleh konsumen ada pada akad yaitu mengenai penimbangan yang dilakukan oleh pihak loundry Chesta. Dalam penimbangan yang dilakukan oleh pihak loundry Chesta mereka tidak memberitahukan berapa berat timbangan tersebut.

Pada bab sebelumnya, sudah dijelaskan mengenai praktik jasa loundry Chesta Balerejo Kabupaten Madiun. Di jasa loundry tersebut tidak ada atau tidak disebutkan nominal harga per kilogram pada saat awal akad untuk mencuci pakaian di loundry tersebut dan tidak mendapatkan kwitansi sebagai bukti transaksi, hanya ketika mengambil pakaian yang sudah selesai di loundry baru mengetahui harga yang harus dibayar oleh konsumen.

Dalam pelaksaannya jasa usaha loundry Chesta ini sudah memenuhi syarat sah akad dimana harus adanya keridaan dari kedua belah pihak yang berakad.

\section{Tinjauan Hukum Islam Terhadap praktik Jasa Laundry Chesta Balerejo Madiun}

Adapun sah atau tidaknya sebuah akad, dapat diketahui dari terpenuhi atau tidaknya rukun dan syaratnya. Oleh karena itu, untuk mengetahu keabsahan praktik jasa loundry Chesta Balerejo Maidun di atas, maka berikut analisisnya:

35 Purnomo (Pemilik loundry), Wawancara, Balerejo 2 Mei 2018. 
1. Al-'aqidayn, para pihak yang terlibat langsung dengan akad. Disini yang dimaksud para pihak yakni pemilik loundry Chesta Balerejo Madiun dan konsumen. Dalam hal ini, kedua orang (subyek) atau pelaku keduannya sudah aqil dan baligh, dan sudah terdiri dari dua orang atau lebih.

2. Mahalul 'aqd, obyek akad, yakni sesuatu yang kehendak diakadkan. Di sini objek akad yang dmaksud yakni berupa jasa, yang mana jasa adalah suatu barang yang tidak dilarang oleh syara' (boleh atau mubah). Barang tersebut yakni berupa baju, selimut, boneka, dll.

3. Sighat al-'aqd, yakni pernyataan kalimat akad, yang lazimnya dilaksanakan melalui pernyataan ijab dan pernyatan qabul. Di sini kedua belah pihak sudah melakukan ijab dan qabul pada awal transaksi loundry tersebut dan salin rela. Namun dalam praktiknya di jasa loundry tersebut tidak ada atau tidak disebutkan nominal harga per kilogram pada saat awal akad untuk mencuci pakaian di loundry tersebut dan tidak mendapatkan kuitansi sebagai bukti transaksi, hanya ketika mengambil pakaian yang sudah selesai di loundry baru mengetahui harga yang harus dibayar oleh konsumen. Akan tetapi, sighat dalam akad dapat diungkapkan dengan beberapa cara yang sudah dijelaskan dalam bab 2 di antaranya adalah dengan perbuatan. Dalam menetapakan keabsahan akad model ini, para ulama' berbeda pendapat, yaitu:

a. Ulama' Hanabilah dan Hanafiyah diperbolehkan akad dengan perbuatan terhadap barang yang sudah umum diketahui manusia jika tidak umum, maka akad ini dianggap batal, disini yang menjadi objek barang yakni berupa baju, selimut, boneka, dan sebagainya. Dengan demikian, akadnya menjadi sah.

b. Ulama' Malikiyah dan Imam Ahmad berpendapat boleh tetapi dengan syarat harus jelas adanya kerelaan. Baik barang itu secara umum atau tidak. Dalam hal ini seperti apa yang sudah dijelaskan diatas barang tersebut jelas dan sudah diketahui secara umum dan para pelaku akad saling rela dan sepakat sehingga tidak merugikan satu 
sama lain. Maka dalam hal ini, akad dalam praktik jasa loundry diperbolehkan atau tidak dilarang.

c. Ulama' Syafi'iyah, Syiah, dan Dhahiriyah berpendapat bahwa akad tersebut tidak dibenarkan karena tidak ada petunjuk yang kuat akan hal itu. Adapun kerelaan merupakan sesuatu yang samar.

Dalam akad, terkadang tidak menggunakan ucapan, tetapi cukup dengan saling meridhoi Ketentuan ini sejalan dengan bunyi Surat an-Nisa' ayat 29:36

"Hai orang-orang yang beriman, janganlah kamu saling memakan harta sesamamu dengan jalan yang batil, kecuali dengan jalan perniagaan yang Berlaku dengan suka sam-suka di antara kamu dan janaganlah kamu membunuh dirimu. Sesungguhnya Allah adalah Maha Penyayang kepadamu."

Dari analisis di atas dapat diambil kesimpulan bahwa transaksi tersebut sudah memenuhi rukun dan syarat sahnya akad, di mana para pihak atau pelaku akadnya sudah aqil baligh dan terdiri dari dua orang atau lebih. Barang yang menjadi objek transaksi tersebut juga sudah memenuhi ketentuan dalam akad, yakni barang jelas dan diketahui kedua belah pihak. Adapun dalam hal sighat, walaupun pihak loundry tidak menyebutkan secara langsung harga nominal perkilogram tersebut, namun kedua belah pihak tidak ada yang merasa dirugikan dan keduanya sudah saling sepakat satu sama lain. Hal ini diperbolehkan oleh jumhur ulama' kecuali Ulama' Syafi'iyah karena ulama' Syafi'iyah berpendapat bahwa kerelaan para pihak merupakan sesuatu yang samar atau tidak jelas dan tidak ada petunjuk yang kuat mengenal hal ini.

\section{Penutup}

Sebagai akhir dalam pembahasan ini, maka akan dikemukakan kesimpulan yang diperoleh dari penelitian yaitu dalam praktik jasa loundry Chesta Balerejo Madiun, konsumen

\footnotetext{
${ }^{36}$ Departemen Agama Republik Indonesia, Al Qur'an Dan Terjemahnya.84
} 
datang membawa pakaian kotornya untuk diloundry, kemudian pakaian kotor tersebut ditimbang oleh pemilik loundry. Adapun hasil timbangan dan nominal harganya tidak disebutkan serta tidak adanya bukti, baik berupa kuitansi atau nota, sehingga baru diketahui ketika pakaian diambil setelah diloundry. Dalam hal ini, kebanyakan konsumen rela dan tidak merasa dirugikan serta menggunakan lagi jasa tersebut.

Praktik jasa loundry Chesta di atas telah sesuai dengan hukum Islam karena sudah memenuhi rukun dan syarat sahnya akad, di mana pelaku akad sudah 'aqil baligh dan terdiri dari dua orang, objek akad jelas dan diketahui kedua belah pihak. Adapun dalam hal sighat, walaupun pihak loundry tidak menyebutkan secara langsung, namun kedua belah pihak tidak merasa dirugikan dan saling sepakat satu sama lain. Hal ini diperbolehkan oleh jumhur ulama' kecuali ulama' Syafi'iyah.

\section{Daftar Pustaka}

Al-A'qalani, Al-Hafidz Ibnu Hajar. Bulughul Maram, Terj. Hamim Thohari Ibnu M Dalimi. Jakarta: PT Gramedia, n.d.

Al-Fauzan, Shaleh. Fikih Sehari-Hari, Terj. Abdul Hayyie AlKattani. Jakarta: Gema Insani Press, 2005.

Basyir, Ahmad Azhar. Asas-Asas Hukum Muamalah (Hukum

Perdata Islam). Yogyakarta: UII Press, 2000.

Chaudrhry, Muhammad Syarif. Sistem Ekonomi Islam; Prinsip Dasar. Jakarta: Prenamedia Group, 2012.

Departemen Agama Republik Indonesia. Al Qur'an Dan

Terjemahnya. Jakarta: CV Karya Insan Indonesia, 2002. Djamali, Abdul. Hukum Islam. Bandung: Mandar Maju, 1992. Al Hadi, Abu Azam. Fiqh Muamalah Kontemporer. Sidoarjo: CV Cahaya XII, 2014.

Hariyani, Diyah Santi. "'Analisa Kontribusi Pembiayaan Musyarakah, Murabahah Dan Ijārah Terhadap

Profitabilitas (Roe) Pada Bank BNI Syariah."' Skripsi--STIE Dharma Iswara Madiun, 2017.

Harun, Nasrun. Fiqh Muamalat. Jakarta: Gaya Media Pratama, 2000.

Huda, Qomarul. Fiqh Muamalah. Yogyakarta: Teras, 2011. Karim, Helmi. Fiqih Muamalah, n.d. 
Siti Fatimah

Mardani. Fiqih Ekonomi Syariah (Fiqih Muamalah). Jakarta: Kharisma Putra Utama, 2012.

Rachmat, Syafe'i. Fiqh Muamalah Untuk IAIN, STAIN, PTAIS Dan Untuk Umum, Cet I. Bandung: Pustaka Setia, 2001.

Sabiq, Sayyid. Fiqh Sunnah. Bandung: PT. Al-Ma'arif, 1987.

Sahrani, Sohari, and Ruf'ah Abdullah. Fikih Muamalah. Bogor: Ghalia Indonesia, 2005.

Syarifuddin, Amir. Garis-Garis Besar Fiqh. Jakarta: Kencana, 2003.

Yazid, Muhammad. Hukum Ekonomi Islam (Fiqh Muamalah). Sidoarjo: CV Cahaya Intan XII, 2014.

Zuhaili, Wahbah. Fiqih Islam Wa Adillatuhu, 2011.

Afi, Wawancara, Madiun, 15 Februari 2018.

Purnomo (Pemilik loundry), Wawancara, Balerejo 2 Mei 2018 